\title{
28 Research Square \\ Organic Residue Analysis Reveals the Function of Bronze Age Metal Daggers
}

Isabella Caricola ( $\square$ isabellacaricola@gmail.com )

Newcastle University, Newcastle Upon Tyne

Alasdair Charles

Newcastle University, Newcastle Upon Tyne

Jacopo Tirillò

Sapienza University

Fraser Charlton

Royal Victoria Infirmary, Newcastle Upon Tyne

Huw Barton

University of Leicester

Francesco Breglia

Salento University

Alberto Rossi

Officina Temporis

Maria Chiara Deflorian

MUSE - Museo delle Scienze

Anna Maria Marinis

Istituto Superiore per la Protezione e la Ricerca Ambientale ISPRA

Susanna Harris

University of Glasgow

Alessio Pellegrini

Sapienza University

Federico Scacchetti

Archeosistemi

Paolo Boccuccia

Museo delle Civiltà

\section{Monica Miari}

Soprintendenza Archeologia Belle Arti e Paesaggio per la Città metropolitana di Bologna e le Province di Modena, Reggio Emilia e Ferrara

Andrea Dolfini

Newcastle University, Newcastle Upon Tyne 


\section{Research Article}

Keywords: Archaeology, Daggers, Bronze Age, Copper Alloys, Organic Residue Analysis, SEM-EDX, Italy Posted Date: February 3rd, 2022

DOI: https://doi.org/10.21203/rs.3.rs-1258246/v1

License: (c) (i) This work is licensed under a Creative Commons Attribution 4.0 International License. Read Full License

Version of Record: A version of this preprint was published at Scientific Reports on April 12th, 2022. See the published version at https://doi.org/10.1038/s41598-022-09983-3. 


\section{Abstract}

The article discusses results of organic residue analysis performed on ten copper-alloy daggers from Bronze Age Pragatto, Italy, c.1550-1250 BCE. Metal daggers are widespread in Chalcolithic and Bronze Age Europe, yet their social and practical roles are still hotly debated. Are they symbolic or functional? Are they tools or weapons? How were they used? For what tasks and on what materials? The research addresses these questions through a novel application of biochemical staining and SEM-EDX analysis. The method has proved successful in extracting and identifying animal residues located on cutting edges including bone, muscle, and tendons. These are interpreted as evidence of prehistoric carcass butchering and carving. Further residues were observed on blade faces and hafting plates or tangs; these are interpreted as remnants of bone handles and sheaths, the latter made of either wood fibers or processed hide and fur. The readings proposed in the article are validated by original experiments with replica daggers, as detailed in the Supplementary Materials. The analysis and experiments shed new light on Bronze Age metal daggers, showing that they were fully functional tools (and perhaps tool-weapons) primarily utilized for the processing of animal carcasses. This original research result contributes significant knowledge towards interpreting an under-studied, yet socially salient, prehistoric metal artifact.

\section{Introduction}

Daggers are ubiquitous yet poorly understood artifacts from prehistoric Europe. They first appeared almost near-simultaneously in eastern/central Europe, the Alps, and the Italian peninsula in the early 4th millennium BCE (1-4). From the outset, daggers were made from either flint or copper (first alloyed with arsenic, and later with tin) depending on source proximity and cultural preferences. By the early 2nd millennium $B C E$, daggers were being made, used, and exchanged from Crete in the south to Scandinavia in the north, and from the Russian steppes in the east to Ireland in the west. After this cross-material floruit, flint and metal daggers parted ways, with the former all but disappearing from the archaeological record and the latter continuing to be made and used throughout the Bronze Age $(5,6)$.

Early metal daggers were long thought to be non-functional insignia of male identity and power due to perceived weaknesses in design and alloy composition $(7,8)$. Pioneering applications of metalwork wear analysis suggest that this might not be the case. Wall's (9) examination of 55 Early Bronze Age daggers from southern Britain, for example, indicates that protracted use, repairs, and curation were not uncommon. Similarly, Dolfini (10) and laia and Dolfini (11) noticed high rates of edge sharpening coupled with minor edge damage on 15 Chalcolithic daggers from Italy. They proposed that the damage might be due to contact with soft materials such as animal tissue. Generally, size reduction due to repeated sharpening is common on prehistoric metal daggers, denoting a preoccupation for keeping these objects sharp throughout their use lives $(12,13)$.

None of these studies is conclusive due to their narrow regional and chronological samples. Even if deployed on larger assemblages, however, usewear analysis is unlikely to address broad questions concerning the function of early metal daggers due to (a) high rates of edge corrosion; (b) certain uses 
not leaving discernible traces; and (c) some of the traces being unspecific. Under these circumstances, insights into dagger uses can be provided by the organic residues trapped in the objects' corroded surfaces, or by their imprints, which may reveal the substances they had been in contact with. Such an approach has long been applied to ancient stone, shell, and ceramic artifacts but never (to the best of our knowledge) to copper-alloy tools or weapons (14-22).

In this paper, we discuss non-destructive organic residue analysis as performed on ten freshly excavated copper-alloy daggers from Pragatto, a Bronze Age domestic site in northern Italy. We present (a) the site and context; (b) results of qualitative residue analysis carried out on the daggers; (c) results of SEM-EDX analysis; and (d) details of the analytical method. We demonstrate that the research sheds new light on the uses of Bronze Age daggers. Importantly, the approach presented here can be replicated on other copper-alloy tools and weapons from world prehistory. It is therefore a significant addition to the analytical toolkit available to students of the human past.

\section{Archaeological Context}

Pragatto (Bologna, Italy) is a prehistoric settlement site excavated in 2016-2017 (23). The site is part of the broader Terramare settlement system, which characterized human occupation of the Po River valley, northern Italy, in the Middle and Late Bronze Age, c.1650-1200 BCE (24). The Terramare system emerged in the early stages of the Middle Bronze Age due to combined demographic growth, likely population transfer from Alpine lake-side villages, and a novel ability to manage wet and riverine landscapes, which enabled large-scale crop cultivation of heavy alluvial soils $(25,26)$.

Terramare sites are square villages ranging from 1 to 20 hectares in size. They were normally built near rivers or streams, whose courses were diverted to fill in the ditches surrounding the sites; embankments and palisades also encircled most sites $(27,28)$. The Terramare settlement system provided a stable framework for sociopolitical organization in north-eastern Italy until the advanced Bronze Age. The system dramatically collapsed c.1200 BCE due to either climatic deterioration or political instability, and perhaps both $(28,29)$.

At Pragatto, controlled excavations covered a 6,900 sqm area (Fig. 1A) corresponding to the southern portion of the Bronze Age village (Fig. 1B, areas A and B) and surrounding ditch and banks (Fig. 1B, area C). Site stratigraphy and cultural materials were found to be best preserved in area $B$ thanks to a large fire that swept through the village in prehistoric times. Here, investigations revealed nine burnt-down houses, refuse pits, animal pens, and other features. Due to its excellent preservation, area $B$ returned large numbers of portable finds including over 150 bronzes, e.g., daggers, arrowheads, and craft tools of various descriptions $(23,30)$.

Ten daggers were selected for the research, eight from area B and two from area A (Fig. 1C). The sample offers a broad range of blade morphologies, lengths, and hafting arrangements widespread in the Bronze Age including leaf-shaped and triangular blades. Except for one specimen, whose bronze handle was cast with the blade (Fig. 1C, 8), all dagger blades were riveted to handles made of now-disappeared organic 
materials. Chronologically, the daggers span the period from $c .1550-1250$ BCE, as revealed by their find contexts and distinctive typologies (SI Appendix, S1).

\section{Results}

Microscopic observation and SEM-EDX analysis revealed traces of organic residues preserved on the cutting edges, blades, and hafting plates or tangs of the daggers. Using Picro-Sirius Red (PSR) solution as a staining material allowed us to identify micro-residues of collagen and associated bone, muscle, and bundle fibers of tendon, suggesting that the daggers had come into contact with multiple animal tissues. SEM observation showed the residues to be clustered along the cutting edges and at the junction between dagger blade and hafting plate/tang. The residues were mostly trapped within metal corrosion products and striations sited on cutting edges, which we interpret as use marks $(10,11)$. A similar association of organic residues and striations was observed on replica daggers used for experimental butchering and the working of hard and soft animal tissues (SI Appendix, S2). The interpretation presented here is supported by SEM-EDX analysis of the residues extracted from the archaeological daggers. The analysis revealed abundant hydroxyapatite (HA), a calcium phosphate present in the mineral fraction of the bone (31).

Previous research clarifies the conditions - such as contact between organic matter and the copper metal - that prevent bacterial decomposition while preserving animal tissue intact. Langejans (32) demonstrates that combined salt and metals can inhibit the activity of microbes and enzymes, enabling protein-muscle tissue to survive. Likewise, Grömer (33) argues that the acids and tannin contained in soil sediments (e.g., peat bogs) enable preservation of protein-rich organic matter (e.g., wool, skin, hair, and horn), while Janaway $(34,35)$ makes a similar argument for textiles preserved within metal corrosion products.

\subsection{Organic residues}

Organic residues were searched for on all ten daggers. Areas observed included blade face, cutting edge, point, and hafting plate or tang (both sides). We identified organic residues on eight specimens (SI Appendix Tab. S2, S3). The residues belonged to the following categories: 1) type I and III collagen (36), mainly clustering on the cutting edges; these are interpreted as use-derived residues (Fig. 2); 2) mineralized residues of fibers belonging to (a) several species of plants, one of which appears to be $c f r$. Alnus (SI Appendix, Section S1); these are interpreted as remnants of dagger sheaths an artefact types known from the Alpine Iceman's lime tree bast dagger sheath (37); and (b) worked non-determined animal fur, which is also interpreted as a dagger sheath residue (Fig. 3; SI Appendix, S1); 3) bone residues clustering on the hafting plates or tangs, which are interpreted as handles or handle plates (SI Appendix,

section S1); and 4) soil contamination including starch grains of Triticeae, feathers, raphides (i.e., calcium oxalate crystals), and an animal hair. Examination of a soil sample associated with one of the daggers supports our view that these are environmental contaminants, not use-derived residues (SI Appendix, section S1-Fig.S3). 
Micro-residues were sampled from the eight daggers using the PSR staining procedure described below (see Methods). The residues were mostly embedded in the metal corrosion patina coating the objects. Corrosion is a natural alteration process affecting most types of metal and alloy, which is caused by a wide variety of factors, most commonly electrochemical reactions and oxidation. Depending on taphonomic conditions (e.g., temperature, $\mathrm{pH}$, and soil composition), minerals and crystals may grow on the metal itself; their structures depend on the type of organic matter they have been in contact with (38). Dagger corrosion showed under the microscope as irregular bands or spots ranging in color from green to orange/red, associated with inter-granular attack and pit formation (SI Appendix, section S1). Similar corrosion structures developed on the replica daggers used in carcass-processing experiments (SI Appendix, section S2).

Overall, results of microscopic observation and analysis of use-derived organic residues (point 1 above) can be summarized thus: A) three types of micro-residues are interpreted as bone, namely: A1) clumps of bone flakes with an angular outline, characterized by a high birefringence and appearing predominantly red in cross-polarized light, with rare yellow/orange spots (Fig. 2, a-b); A2) amorphous compact residues with a rough or cratered surface and peripheral crystalline fragments; under cross-polarized light, these residues appear red with medium-high birefringence (Fig. 2, c-f); A3) bone tissue with longitudinal grooves (Fig. 2, g-h). B) Fibers, namely B1) bundles of fiber interpreted as tendons, appearing red in crosspolarized light with medium-high birefringence (Fig. 2, i-p); B2) parallel reticula of fibers that are interpreted as muscle; they appear orange and green in cross-polarized light with a medium-low birefringence (Fig. 2, q-r). C) Unidentifiable amorphous residues (Fig. 2, s-t). All types of residue are described in Tables (SI Appendix Tab. S2, S3).

\subsection{SEM-EDX analysis}

Scanning Electron Microscopy coupled with Energy-Dispersive X-Ray analysis (SEM-EDX) was performed on five daggers from the sample. High-power observation and microprobe analysis were carried out on multiple spots $(4 \leq p \geq 8)$ on both faces of the blades and hafting plates or tangs. The analysis highlighted mineralized areas rich in organic residues, as well asbetter preserved areas that were selected for alloy composition analysis (Fig. 4, a). All specimens analyzed displayed varying amounts of Sn with traces of $\mathrm{Fe}$, as is common for Middle-Late Bronze Age metals from northern Italy; no As or $\mathrm{Pb}$ were detected $(39,40)$. Corrosion structures including cracks and flaked surfaces were observed under the SEM. As one would expect, these were concentrated along blade edges where the metal is thinnest and most susceptible to degrading (Fig. 4, f-h).

Specimen no 1707 returned some of the best-preserved organic residues in the sample. SEM-EDX analysis revealed traces of fur fibers, which we interpret as remnants of a dagger sheath. The fibers were associated with $\mathrm{Cu}$ and a C-O-Si-Al compound likely resulting from the sheath's mineralized fur/hair remains (Fig. 4, c-d). Residues consisting of dark amorphous matter were also observed (Fig. 4, e). These are located along the cutting edge and trapped within use-generated striations. Their analysis returned an association of $\mathrm{Ca} / \mathrm{P}$ in a reasonable ratio (specimen no 1707, Fig. 4, Atomic\% ratio $\mathrm{Ca} / \mathrm{P}$ point $\mathrm{b}=1.43$; $\mathrm{Ca} / \mathrm{P}$ point $\mathrm{e}=1.35$; Weight $\%$ ratio $\mathrm{Ca} / \mathrm{P}$ point $\mathrm{b}=1.85$ and point $\mathrm{e}=1.75$ ). Specimen no 1798 yielded 
similar results (Atomic\%=1.33 and Weight $\%=1.73$ ). These parameters are indicative of hydroxyapatite $\mathrm{Ca}_{10}\left(\mathrm{PO}_{4}\right)_{6}(\mathrm{OH})_{2}$, a calcium phosphate present in the mineral fraction of the bone (31).

An important feature of hydroxyapatite is its stability relative to other calcium phosphate compounds under physiological conditions including temperature, $\mathrm{pH}$, and composition (41). Published experiments show that heated bone has elemental atomic percentage values between 1.07-1.67 for defleshed bone and between 1.42-1.93 for fleshed bone. Weight percentage values of defleshed bone lie between 1.662.35 , while the bracket is 1.84-2.50 for fleshed bone (41). These values are broadly in line with those observed on specimens 1707 and 1798, as is their $\mathrm{Ca}$ /P atomic ratio (as determined by EDX analysis) visà-vis the literature $(17,22,42,43 ;)$. Overall, these studies support our view that the daggers from Pragatto had been in contact with bone tissue.

\section{Discussion}

The function of prehistoric copper-alloy daggers has long been debated, with the controversy often extending to coeval flint daggers $(5,44)$. Traditionally, these objects were viewed as symbolic signifiers of male identity and power - a reading predicated upon dagger-rich warrior burials $(45,46)$. Not all authors agree with this view, however. Some scholars suggest that daggers would be placed in warrior burials following lifetime deployments as close-range weapons (47-49). This reading is supported by occasional skeletal injuries that may have been inflicted by daggers (50-52). Other scholars maintain that daggers might have been multifunctional tool-weapons, or perhaps specialized tools employed in the ritual slaughtering of livestock (53-55). The debate is largely speculative due to the scarce scientific data.

The research discussed in these pages has remedied the situation. The data emerging from integrated organic-residue and SEM-EDX analysis, validated by experiments with replica daggers, indicate that prehistoric metal daggers were used to process animal carcasses. The evidence shows interaction with both hard and soft tissues. This suggests that daggers were used for a wide range of tasks that followed (and perhaps comprised) the slaughter of farm animals and game including butchering the carcass and carving the meat from the bone (as shown by notable bone, tendon, and muscle residues). The evidence tallies with the usewear studies reviewed above, which point to a widespread desire for keeping daggers sharp throughout their use lives. It is also in line with Pragatto being a settlement site where animal husbandry was extensively practiced (23) and our own experiments, which documented how effective these tools can be in detaching soft tissue from the bone.

Significantly, the reading proposed here is independently validated by the microwear analysis of butchered animal remains from Chalcolithic and Bronze Age sites, which frequently show metal cut marks (56-60). Of course, daggers may have had additional uses, e.g., as close-range weapons. Further research is needed to build a comprehensive functional interpretation of early metal daggers; this is now possible thanks to the replicable methodology detailed below. 


\section{Materials And Methods}

\subsection{Experiments with replica daggers}

Eight bronze daggers were cast, finished, and sharpened using prehistoric technologies and methods. The replicas were based on European Chalcolithic and Bronze Age templates including blade geometries close to the specimens from Pragatto. The replicas were cast from two alloy compositions: $4 \%$ tin-bronze $(n=3)$, providing a compositional proxy for Early to Middle Bronze Age low-tin alloys, and $10 \%$ tin-bronze $(n=5)$, reflecting Middle to Late Bronze Age high-tin alloys. All replicas were subjected to a single cycle of mechanical edge hardening and were subsequently sharpened.

All daggers were utilized for cutting, scraping, and drilling activities lasting from 3-5 h each (SI Appendix, section S2). The experimental protocol encompassed three phases: (1) four daggers were used to process animal bone, tendons, muscles, and cartilage; their residues were then isolated on the objects and described through microscopic observation; (2) two daggers were used for butchering and carving the carcass of a pig (Sus scrofa) and of a red deer (Cervus elaphus); this helped us to document associations between residues; and (3) two daggers were used to work green and dry wood and harvest Triticum monococcum and Triticum dicoccum wheat. Seven to ten days after use, we observed oxidation structures appearing on top of the plant and animal residues, whose color ranged from orange/green to black. The residues and corrosion structures were observed and described using the microscopes discussed in 5.2 (SI Appendix, section S2; Figs.S5-S8).

\subsection{Organic residue and SEM-EDX analysis}

Ten archaeological daggers and eight experimental replica daggers were analyzed at the Wolfson Archaeology Laboratory, Newcastle University (UK), searching for macroscopic and microscopic organic residues. Macro-residues were observed using (1) a binocular stereomicroscope Leica EZ4 W with integrated 5-megapixel camera (magnification range 8x-35x); and (2) a reflected-light metallographic microscope Res Micro Leica DM2700 MH RL with integrated LEICA MC170 HD camera (magnification range 5x-50x). Micro-residues were observed under a trinocular polarizing microscope Res Micro Leica DM750P with built-in LEICA MC170 HD camera. The microscope had progressive magnifications, i.e., 5x$10 x-20 x-65 x$ and a 100x immersion-oil lens. Subsequently, the archaeological daggers were observed and chemically characterized at the Department of Engineering, Sapienza University of Rome (Italy) using a field-emission SEM (MIRA3 by Tescan) equipped with an EDX detector (EDAX - Octane Elect, model Elect Plus, Sensor Area: $30 \mathrm{~mm} 2$ ), while the replica daggers were examined at Newcastle University (UK), Faculty Analytical SEM Unit, using a Jeol 5610LV SEM with an Oxford 'X-act' thin-window EDX system for elemental analysis. Prior to SEM-EDX analysis, both archaeological and replica daggers were gently washed with ultra-pure water to remove any adhering sediment. The objects were not treated or conserved until after completion of the analysis so as not to jeopardize data collection and interpretation.

\subsection{Sampling and description of macro- and micro- residues}


Macro-residue description followed the procedures discussed by Fullagar and Matheson (61); Hayes and Rots (17); and Lombard (62). Variables of interest encompass localization, color, morphology or structure, appearance, and birefringence. Following Stephenson (36), we developed a micro-residue sampling and observation protocol using the biochemical staining Picro-Sirius Red Solution (PSR) (ab246832Abcam $\left.{ }^{\circledR}\right)$. This is a strongly acidic azo dye used in histology to stain biological tissues and collagen surviving in millennia-old archaeological contexts $(15,63)$. Importantly, PSR is proven not to alter the morphology and structure of plant residues such as starch grains and phytoliths (64-66). Once treated with PSR and observed under cross-polarized light, Type I collagen appears as thick, strongly birefringent red or yellow fibers; Type II collagen displays a weak birefringence of varying color; and Type III collagen appears as thin, weakly birefringent green fibers $(36,67)$.

Samples were taken from $10 \leq p \geq 15$ points on the dagger surfaces on both sides of the blades focusing on tips, cutting edges, and hafting plates or tangs. The samples were taken from oxidized structures as well as other spots where low-power microscopy had revealed details of interest. Both archaeological and experimental daggers were sampled. Two methods of micro-residue sampling were tested, namely (1) wet sampling using a pipette and mineralized water, and (2) dry sampling. We found dry sampling to provide higher amounts of residue and thus to be preferable to wet sampling. Dry sampling is also advantageous for long-term sample storage since it does not wet or alter the metal specimen. We extracted the dry samples using a sterile probe or scalpel (in the latter case using the blunt edge of the tool to avoid scratching the metal). We found it sufficient to take $0.5-1 \mathrm{mg}$ of corroded metal and place it in a sterile microcentrifuge tube.

The next step of the analysis took place in a sterile laboratory environment. The dry sample was placed in a sterilized agate mortar and finely pulverized, adding 3-4 drops of ultra-pure water with a Pasteur glass pipette. The pulverized sample was then placed on a clear slide using a micro-pipette. As two drops are normally sufficient for the analysis, the same sample may be used for several slides. The slide was left open (i.e., without glass cover) in a petri dish and allowed to dry in a biosafety cabinet to limit contamination. Subsequently, the PSR stain was applied following the protocol described by Stephenson (36). The tissue was completely covered with PSR solution and left to incubate for 60 minutes. The slide was then rapidly rinsed with Acetic Acid Solution (0.5\%). Finally, a mounting media (50\% glycerol and $50 \%$ ultra-pure water) was placed on the stained area and covered with a coverslip. The coverslip was not sealed to allow subsequent rehydration of the sample, as needed. The sample was then ready to be observed in both transmitted and cross-polarized light.

\section{Declarations}

\section{Acknowledgements and Funding Sources}

The research was carried out as part of the EU-funded EuroDag project, a Marie-Sklodowska Curie Fellowship, Grant Agreement no 798688. We thank Dr Isabel Arce-Garcia of the SEM analytical unit, Newcastle University, for preparing the samples. We also thank Professor Cristina Lemorini and the LTFAPA laboratory team from Sapienza University, Rome, for supporting the research. 


\section{Author contributions:}

I.C. and A.D. designed research; I.C. performed research; I.C., A.D., A.C., J.T, F.C., F.B., M.C.D., A.M.D., H.B., S.H., A.P., A.R. analyzed data; M.M., P.B., F.S. responsible of the archaeological excavation; all the authors wrote the paper.

\section{Data availability}

All data generated or analysed during this study are included in this published article [and its supplementary information files].

\section{References}

1. Dolfini A. The origins of metallurgy in central Italy: New radiometric evidence, Antiquity, 84, pp. 707723 (2010).

2. Hansen S. Innovative Metals: Copper, gold, and silver in the Black Sea region and the Carpathian Basin during the 5th and 4th millennium BC, in Metal Matters: Innovative Technologies and Social Change in Prehistory and Antiquity, S. Burmeister, S. Hansen, M. Kunst, N. Müller-Scheebel, Eds. (Rahden: Marie Leidorf, 2013), pp. 137-167.

3. Mottes M. Bell Beakers and beyond: Flint daggers of northern Italy between technology and typology. In Bell Beakers Today: Pottery, People, Culture, Symbols in Prehistoric Europe, F. Nicolis, Ed. (Trento: Provincia Autonoma di Trento, 2001), pp. 519-545.

4. Müller J. Missed innovation: The earliest copper daggers in northern-central Europe and southern Scandinavia in Counterpoint: Essays in Archaeology and Heritage Studies in Honour of Professor Kristian Kristiansen, S. Bergerbrant, S. Sabatini, Eds. (Oxford: Archaeopress, 2013), pp. 443-448.

5. Frieman C.J. Innovation and Imitation: Stone skeuomorphs of metal from 4th-2nd millennia BC northwest Europe (Oxford: Archaeopress, 2012).

6. Frieman C.J., Eriksen B.V. Eds. Flint Daggers in Prehistoric Europe, (Oxford: Oxbow, 2015).

7. Avery D.H., Grossman V.V., Eaton E.R. Metallurgical analysis of copper and bronze objects in Buccino: The Eneolithic Necropolis of S. Antonio and Other Discoveries Made in 1968 and 1969 by Brown University, R. Ross Holloway, Ed. (Rome: De Luca, 1973), pp. 113-114.

8. Keates S. The flashing blade: copper, colour and luminosity in North Italian Copper Age society, in Colouring the past: The Significance of Colour in Archaeological Research, A. Jones, G. MacGregor, Eds. (Oxford, UK. Berg, 2002) pp. 109-125.

9. Wall J. The role of daggers in Early Bronze Age Britain: The evidence of wear analysis. Oxford Journal of Archaeology, 6(1), pp. 115-118 (1987).

10. Dolfini A. The function of Chalcolithic metalwork in Italy: An assessment based on use-wear analysis. Journal of Archaeological Science, 38(5), pp. 1037-1049 (2011). 
11. Iaia C., Dolfini A. Manufatti eneolitici in lega di rame dall'area di Roma: un'indagine su tracce di processi tecnologici e di usura, in, Roma prima del mito. Abitati e necropoli dal neolitico alla prima eta' dei metalli nel territorio di Roma (VI-III millennio a.C.), vol. 2, A.P. Anzidei, G. Carboni, Eds. (Oxford: Archaeopress, 2020) pp. 549-568.

12. Aranda-Jiménez G., Montón-Subías S., Jiménez-Brobeil S. Conflicting evidence? Weapons and skeletons in the Bronze Age of south-east Iberia. Antiquity, 83 (322), 1038-1051 (2009).

13. Rassmann K. Spätneolithikum und frühe Bronzezeit im Flachland zwischen Elbe und Oder, Beiträge zur Ur-und Frühgeschichte Mecklenburg-Vorpommerns 28, (chwerin: Archaologisches Landesmuseum fur Mecklenburg-Vorpommern, 1993).

14. Cristiani E., Borić D. 8500-year-old Late Mesolithic garment embroidery from Vlasac (Serbia): Technological, use-wear and residue analyses. Journal of Archaeological Science, 39(11), 34503469 (2012).

15. Croft S. Lithic Residues Analysis (Oxford: British Archaeological Reports, 2021).

16. Hayes E., Cnuts D., Rots V. Integrating SEM-EDS in a sequential residue analysis protocol: benefits and challenges. Journal of Archaeological Science: Reports, 23, pp.116-126 (2019).

17. Hayes E., Rots V. Documenting scarce and fragmented residues on stone tools: an experimental approach using optical microscopy and SEM-EDS. Archaeological and Anthropological Sciences, 11(7), pp. 3065-3099 (2019).

18. Heron C., Evershed R. P. The analysis of organic residues and the study of pottery use. Journal of Archaeological Method and Theory, 5, pp. 247-284 (1993).

19. Martín-Viveros J. I., Ollé A. Use-wear and residue mapping on experimental chert tools. A multi-scalar approach combining digital 3D, optical, and scanning electron microscopy. Journal of Archaeological Science: Reports, 30, 102236 (2020).

20. Monnier G., May K. Documenting the degradation of animal-tissue residues on experimental stone tools: a multi-analytical approach. Archaeological and Anthropological Sciences, 11(12), pp. 68036827 (2019).

21. Pedergnana A., Ollé A. Building an experimental comparative reference collection for lithic microresidue analysis based on a multi-analytical approach. Journal of Archaeological Method and Theory, 25(1), pp. 117-154 (2018).

22. Venditti F., Agam A., Tirillò J., Nunziante-Cesaro S., Barkai R. An integrated study discloses chopping tools use from Late Acheulean Revadim (Israel). Plos One, 16(1), e0245595 (2021).

23. Miari M., Boccuccia P., Barbieri M., Bosi G., Carra M.L., Cremaschi M., Curci A., De Angelis A., Gabusi R., Lemorini C., Maini E., Mariani G.S., Mercuri A.M., Pavia F., Scacchetti F., Stellacci S. Gli scavi alla Terramara di Pragatto (BO): dai primi dati al progetto di ricerca, in Atti del Convegno di Studi in onore di Maria Bernabò Brea, M. Maffi, L. Bronzoni, P. Mazzieri, P., Eds. (Piacenza: Archeotravo Cooperativa Sociale, 2019), pp. 229-239.

24. Nicolis F. Northern Italy, in The Oxford Handbook of the European Bronze Age, H. Fokkens, A. Harding, Eds. (Oxford: Oxford University Press, 2013), pp. 693-705. 
25. De Marinis R.C. L'età del Bronzo nella regione benacense e nella pianura padana a nord del Po, in $L e$ Terramare. La più antica civiltà padana, M. Bernabò Brea, A. Cardarelli, M. Cremaschi, Eds. (Milan: Electa 1997), pp. 405-419.

26. Vanzetti A. 1600 ? The rise of the Terramara system (Northern Italy), in 1600 - Cultural Change in the Shadow of the Thera Eruption? H. Meller, F. Bertemes, H.R. Bork, R. Risch, Eds. (Halle, Saale: Landesmuseums für Vorgeschichte Halle, 2013), pp. 267-282.

27. Bernabò Brea M., Cardarelli A., Cremaschi M. Le Terramare. La più antica civiltà padana (Milan: Electa, 1997).

28. Cardarelli A. The collapse of the Terramare culture and growth of a new economic and social system during the Late Bronze Age in Italy. Scienze dell'Antichità, 15, pp. 449-520 (2010).

29. Cremaschi M., Pizzi C., Valsecchi V. Water management and land use in the Terramare and a possible climatic co-factor in their abandonment: The case study of the Terramara of Poviglio Santa Rosa (northern Italy). Quaternary International, 151(1), pp. 87-98 (2006).

30. Miari M., Boccuccia P., Cattani M., Cremaschi M., Scacchetti F., Trogi F. La Terramara di Pragatto (BO): primi dati sull'organizzazione spaziale del sito, in Preistoria e Protostoria in Etruria. Atti del Quattordicesimo Incontro di Studi, N. Negroni Catacchio, Ed (Centro Studi di Preistoria, Milano, 2020), pp. $169-180$.

31. Orlovskii V. P., Komlev V. S., Barinov S. M. Hydroxyapatite and hydroxyapatite-based ceramics. Inorganic materials, 38(10), pp. 973-984 (2002).

32. Langejans G. H. Remains of the day-preservation of organic micro-residues on stone tools. Journal of Archaeological Science, 37(5), pp. 971-985 (2010).

33. Grömer K. The Art of Prehistoric Textile Making: The development of craft traditions and clothing in Central Europe (Natual History Museum Vienna, 2016).

34. Janaway R. C. Textile fibre characteristics preserved by metal corrosion: the potential of SEM studies. The Conservator, 7(1), pp. 48-52 (1983).

35. Janaway R. C. Dust to dust: the preservation of textile materials in metal artifact corrosion products with reference to inhumation graves. Science and archaeology, 27, pp. 29-34 (1985).

36. Stephenson B. A modified Picro-Sirius Red (PSR) staining procedure with polarization microscopy for identifying collagen in archaeological residues. Journal of Archaeological Science, 61, pp. 235-243 (2015).

37. Oeggl K. The significance of the Tyrolean Iceman for the archaeobotany of Central Europe. Vegetation History and Archaeobotany, 18(1), pp.1-11 (2009).

38. Piccardo P., Mödlinger M., Ghiara G., Campodonico S., Bongiorno V. Investigation on a "tentacle-like" corrosion feature on Bronze Age tin-bronze objects. Applied Physics A, 113(4), pp. 1039-1047 (2013).

39. Junghans S., Sangmeister E., Schröder M. Metallanalysen kupferzeitlicher und frühbronzezeitlicher Bodenfunde aus Europa. Studien zu den Anfängen der Metallurgie-SAM 1 (Berlin: Gebr. Mann Verlag. 1960). 
40. Junghans S. Kupfer und Bronze in der frühen Metallzeit Europas. Studien zu den Anfängen der Metallurgie-SAM 2.4 (Berlin: Gebr. Mann Verlag. 1974).

41. Ellingham S. T., Thompson T. J., Islam M. Scanning Electron Microscopy-Energy-Dispersive X-Ray (SEM/EDX): A Rapid Diagnostic Tool to Aid the Identification of Burnt Bone and Contested Cremains. Journal of Forensic Sciences, 63(2), pp. 504-510 (2018).

42. Christensen M. Le Travail et l'Usage de l'Ivoire au Paleolitique Supérieur. Tracéologie des Outils en Silex et Caractérisation Chimique des Polis d'Utilisation. Unpublished PhD dissertation, Université Paris I (1997).

43. Nganvongpanit K., Siengdee P., Buddhachat K., Brown J.L., Klinhom S., Pitakarnnop T., Angkawanish T., Thitaram C. Anatomy, histology and elemental profile of long bones and ribs of the Asian elephant (Elephas maximus). Anatomical science international, 92(4), pp. 554-568 (2017).

44. Frieman C.J. Flint daggers, copper daggers, and technological innovation in Late Neolithic Scandinavia. European Journal of Archaeology, 15(3), pp. 440-464 (2012).

45. Dolfini A. Warrior Graves Reconsidered: Metal, Power and Identity in Copper Age Italy. World Archaeology, in press.

46. Robb J., Harris O.J.T. The Body in History: Europe from the Palaeolithic to the future (Cambridge: Cambridge University Press, 2013).

47. Molloy B. Hunting warriors: the transformation of weapons, combat practices and society during the Bronze Age in Ireland. European Journal of Archaeology, 20(2), pp.280-316 (2017).

48. Molloy B., Horn C. Weapons, Warriors and Warfare in Bronze Age Europe, in The Cambridge World History of Violence: Volume 1: The Prehistoric and Ancient Worlds, G.G. Fagan, L. Fibiger, M. Hudson, M. Trundle, Eds. (Cambridge: Cambridge University Press, 2020), pp. 117-141.

49. Randsborg K. Hjortspring: warfare and sacrifice in early Europe (Aarhus: Aarhus University Press., 1995).

50. Guilaine J., Zammit J. The Origins of War: Violence in prehistory (Malden, MA: Blackwell, 2005).

51. Needham S., Kenny J., Cole G., Montgomery J., Jay M., Davis M., Marshall P. Death by combat at the dawn of the Bronze Age? Profiling the dagger-accompanied burial from Racton, West Sussex. The Antiquaries Journal, 97, pp. 65-117 (2017).

52. Vaquer J., Remicourt M. Les poignards en cuivre et les poignards en silex dans les dotations funéraires chalcolithiques du midi de la France, in Sépultures collectives et mobiliers funéraires de la fin du Néolithique en Europe occidentale (Carcassonne, France., 2010), pp. 238-271.

53. Mödlinger M., Sabatini B. Bronze Age Caucasian metalwork: Alloy choice and combination. Journal of Archaeological Science: Reports, 16, pp. 248-257 (2017).

54. Perucchetti L., Northover J. P., David-Elbiali M. What is a dagger? A metallurgical interpretation of three metal daggers from western Switzerland dated from the Late Neolithic to the Early Bronze Age. Journal of Archaeological Science: Reports, 30, 102251 (2020). 
55. Skak-Nielsen N.V. Flint and metal daggers in Scandinavia and other parts of Europe. A reinterpretation of their function in the Late Neolithic and Early Copper and Bronze Age. Antiquity, 83(320), pp. 349-358 (2009).

56. Bello S. M., Soligo C. A new method for the quantitative analysis of cutmark micromorphology. Journal of Archaeological Science, 35(6), 1542-1552 (2008).

57. Greenfield H. J. The butchered animal bone remains from Ashqelon, Afridar-Area G. Antiqot, 45, pp. 243-261(2004).

58. Larson K., Hardin J. W., Cody S. Cultural modification analyses on faunal remains in relation to space use and direct provisioning from Field VI EBIIIA Tell el-Hesi. Palestine Exploration Quarterly, 152(4), 365-388 (2020).

59. Christidou R. An application of micro-wear analysis to bone experimentally worked using bronze tools. Journal of Archaeological Science, 35(3): 733-751(2008).

60. Cristiani E., Alhaique F. Flint vs. metal: the manufacture of bone tools at Conelle, Italy, in From Hooves to Horns, from Mollusc to Mammoth. Tallinn: International Council for Archaeozoology, $\mathrm{H}$. Luik, A. M. Choyke, C. E. Batey, L. Lougas, Eds. (Tallin, 2005), pp. 397-403.

61. Fullagar R., Matheson M. Traceology: A summary, in Encyclopedia of Global Archaeology C. Smith Ed. (Springer, New York, 2013), pp. 73-85.

62. Lombard M. Distribution patterns of organic residues on middle stone age points from Sibudu Cave, Kwazulu-natal, South Africa. The South African Archaeological Bulletin, Vol. 59, 180, pp. 37-44 (2004).

63. Montes G. S., Krisztan R. M., Junqueira L. C. U. Preservation of elastic system fibers and of collagen molecular arrangement and stainability in an Egyptian mummy. Histochemistry, 83(2), pp. 117-119 (1985).

64. Fullagar R., Hayes E., Stephenson B., Field J., Matheson C., Stern N., Fitzsimmons K. Evidence for Pleistocene seed grinding at Lake Mungo, south-eastern Australia. Archaeology in Oceania, 50, pp. 3-19 (2015).

65. Fullagar R., Stephenson B., Hayes E. Grinding grounds: Function and distribution of grinding stones from an open site in the Pilbara, western Australia. Quaternary International, 427, pp. 175-183 (2017).

66. Hamm G., Mitchell P., Arnold L. J., Prideaux G. J., Questiaux D., Spooner N. A., Vladimir A., Levchenko A., Johnston D. Cultural innovation and megafauna interaction in the early settlement of arid Australia. Nature, 539(7628), pp. 280-283 (2016).

67. Kiernan J. A. Histological and histochemical methods: theory and practice. Shock, 12(6), pp. 479480 (1999).

\section{Figures}



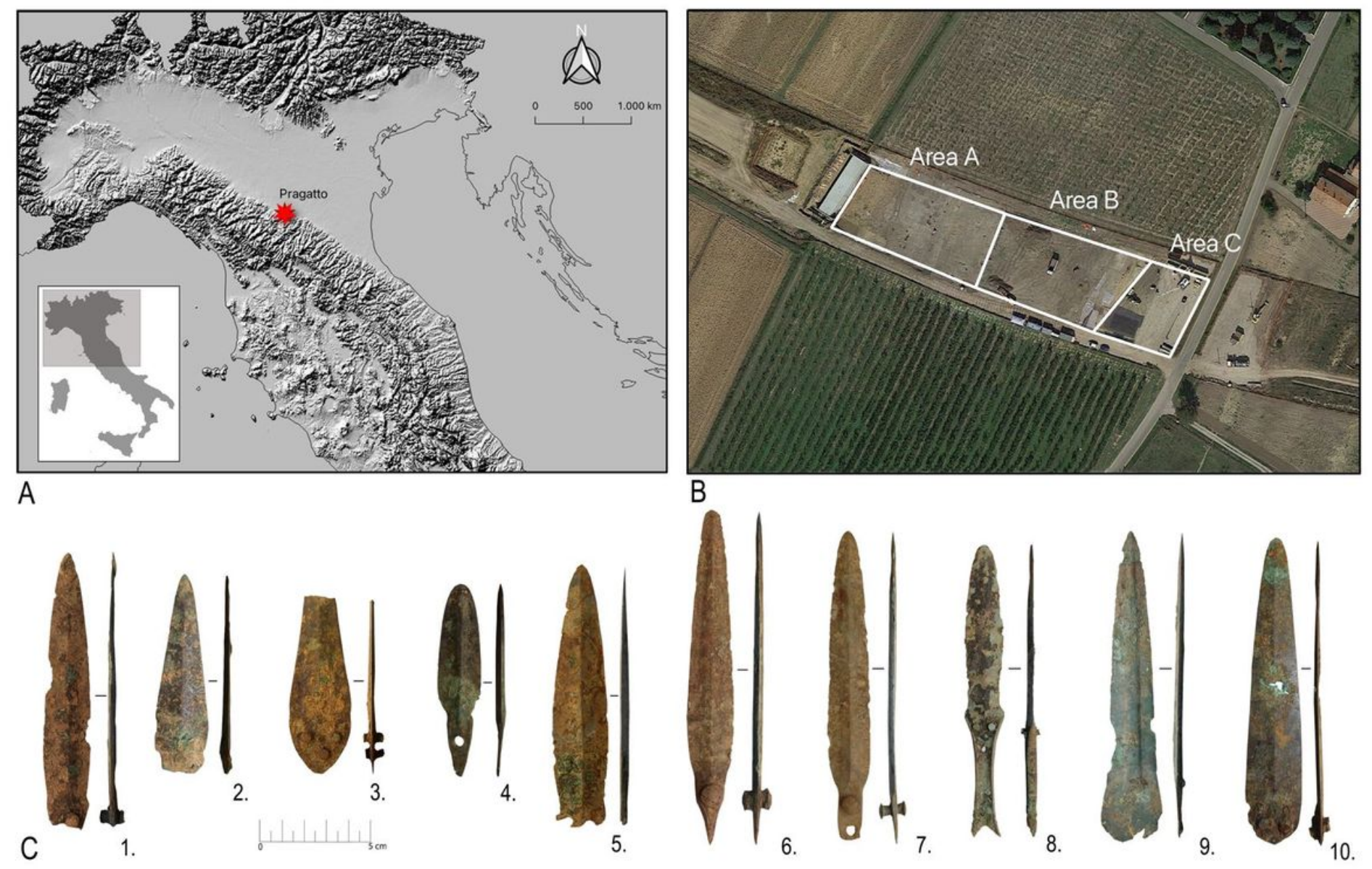

9.

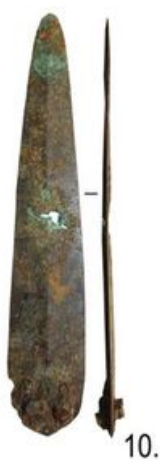

Figure 1

1A: Site location; 1B: Aerial view of the site highlighting excavation areas A, B and C (source: Google Earth); 1C: Copper-alloy daggers analyzed as part of the research. Specimen 1) no 1617; 2) no 2037; 3) no 175 ; 4) no 1707 ; 5) no 2041 ; 6) no 1798 ;) no 2035 ; 8) no 1683; 9) no 1321;10) no 264. 

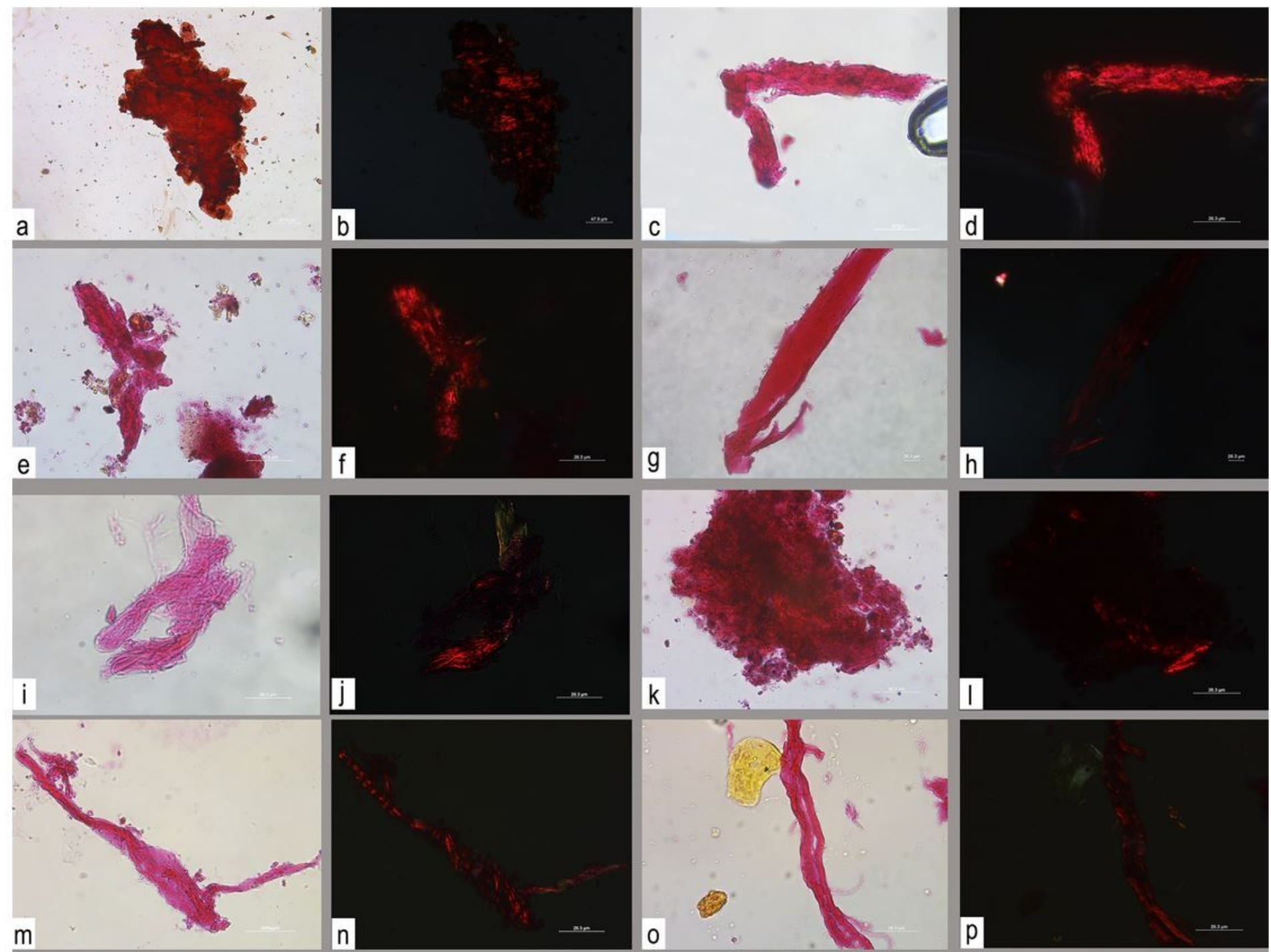

m
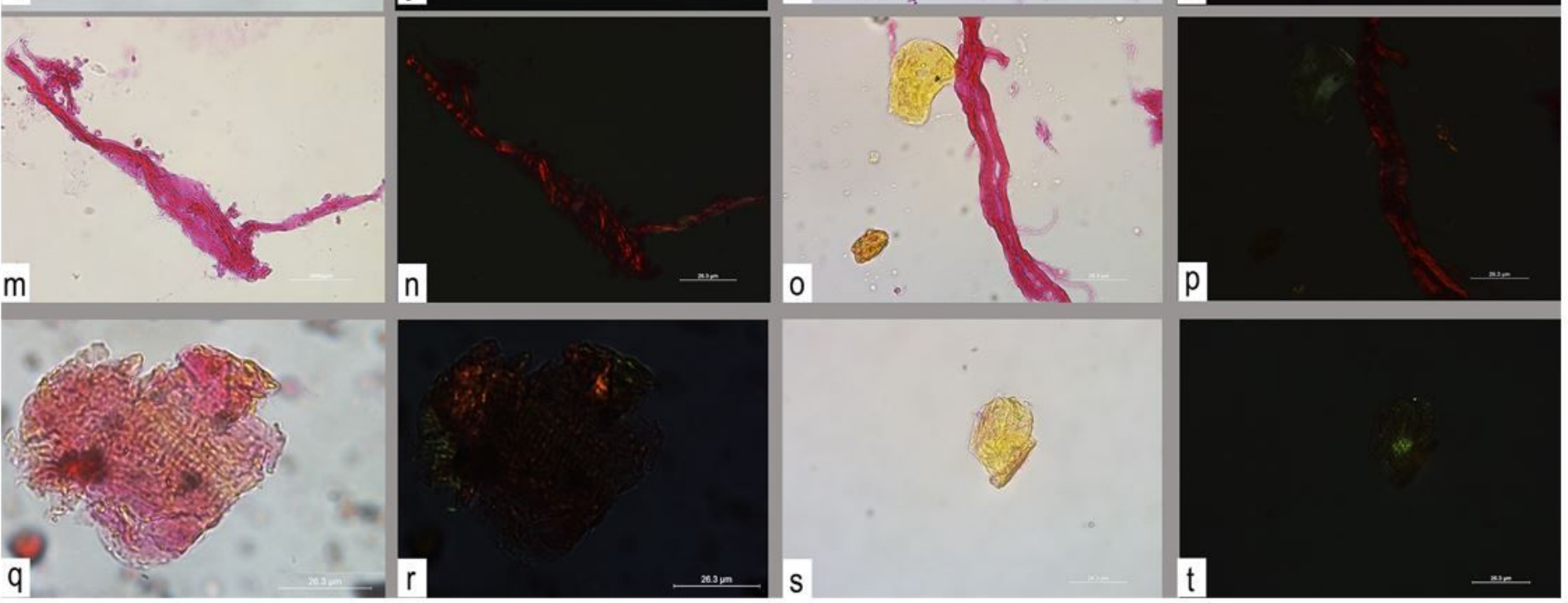

\section{Figure 2}

Archaeological residues observed in transmitted and cross-polarized light with staining compound PSR. a-b) clumps of bone flakes with an angular outline; $\mathbf{b}-\mathbf{f}$ ) amorphous compact residues with a rough/cratered surface and peripheral crystalline fragments; $\mathbf{g}-\mathbf{h}$ ) tissue with longitudinal grooves; i-p) bundles of fiber; q-r) parallel reticula of fiber; s-t) amorphous matter. 

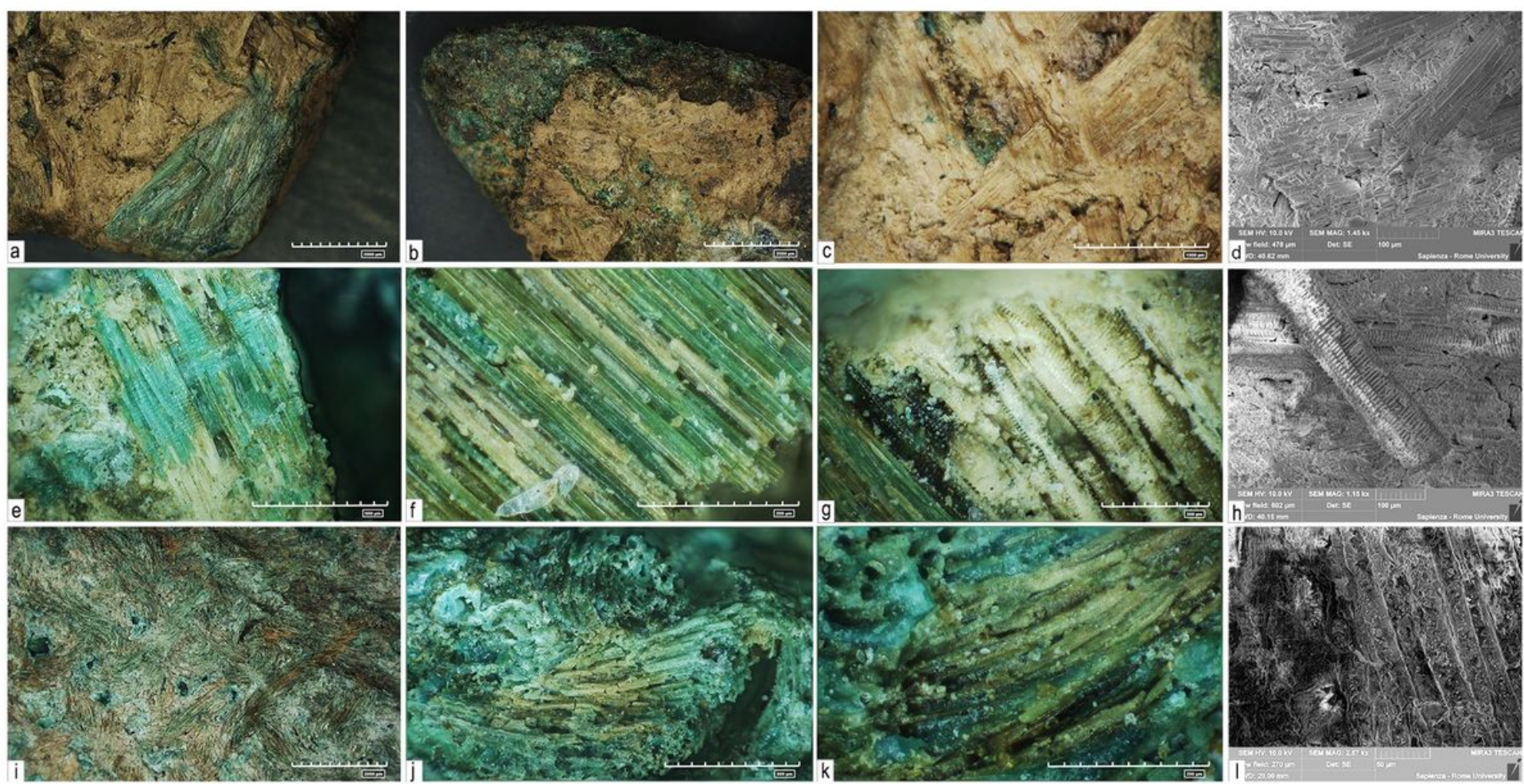

\section{Figure 3}

Residues observed on the copper-alloy daggers from Pragatto, interpreted as remnants of sheaths. $\mathbf{a}-\mathbf{h}$ ) specimen no 2037 observed with an RH-Hirox digital microscope displays intertwined plant fibers interpreted as cfr. Alnus, (h) SEM imaging (MIRA3 by Tescan) of sample no 2037 highlights details of xylem plant cells and water conducting tissues; i-l) specimen no 1707 observed with an RH-Hirox digital microscope displays residues of non-determined fur fibers; I) details of the negative cast of the animal fur residues as observed with a SEM microscope (MIRA3 by Tescan). 

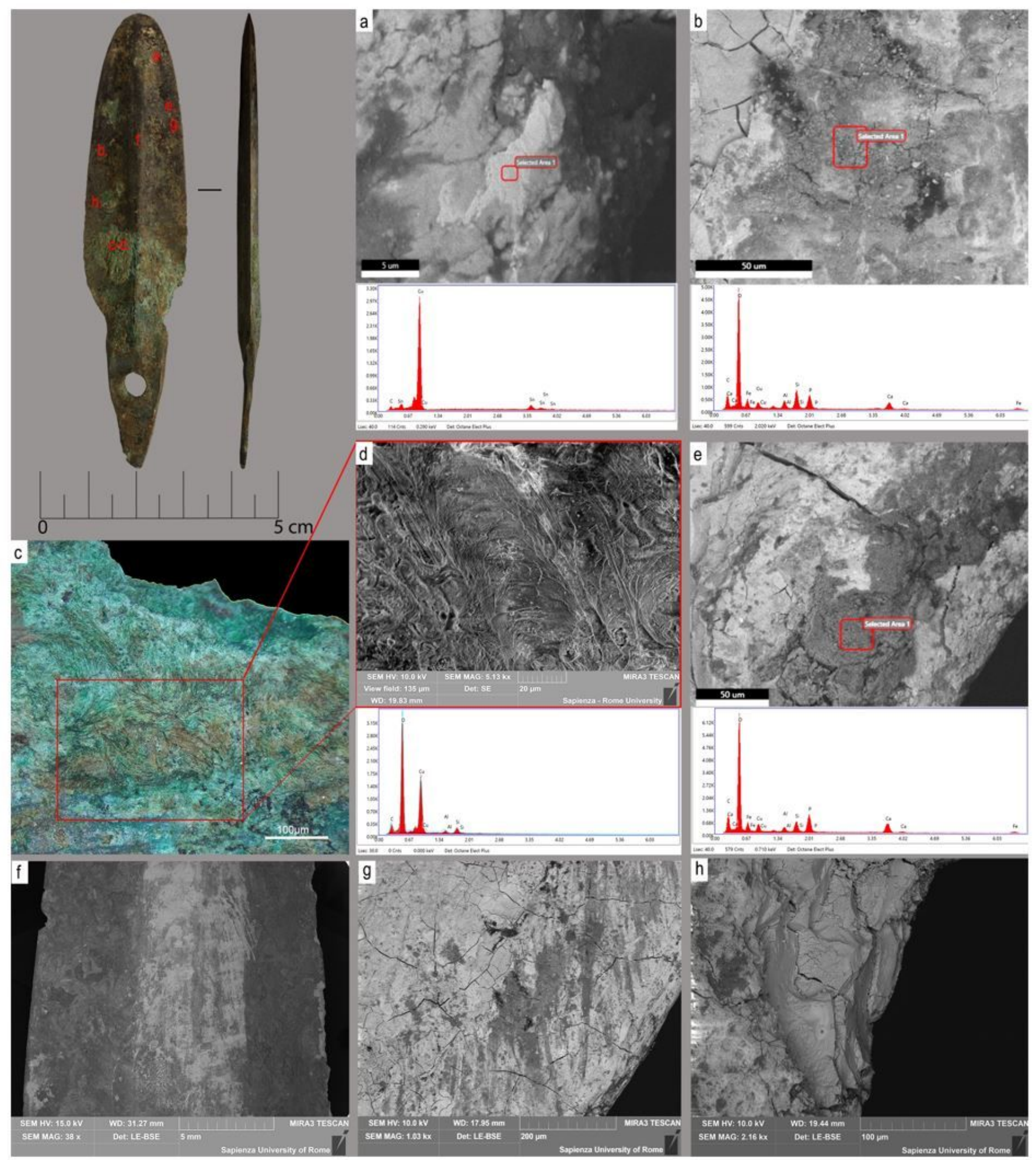

\section{Figure 4}

SEM-EDX analysis of dagger no 1707. a) alloy composition (Cu-Sn); b) analysis of corrosion structures associated with an amorphous residue (C-O-Ca-P); $\mathbf{c}-\mathrm{d}$ ) analysis of mineralized fur fibers associated with a C-O-Cu compound and Si-Al; e) compact amorphous material found along the cutting edge, associated with a C-O-Ca-P compound and Cu; $\mathbf{f}$ ) portion of the blade analyzed by SEM-EDX; $\mathbf{g}$ ) oriented use 
striations associated with organic residues as observed on the cutting edge; $\mathbf{h}$ ) corroded and flaked surface of the dagger blade.

\section{Supplementary Files}

This is a list of supplementary files associated with this preprint. Click to download.

- SupplementaryMaterials.docx 